\title{
Significance of trust in knowledge citizenship
}

Melanie Sutton

Knowledge Officer

The IQ Business Group

msutton@iqgroup.net

\section{Introduction}

The notion of trust, according to Misztal (quoted in a Wikipedia entry), attempts to combine all notions of trust together, pointing out three basic things that trust does in the lives of people: it makes social life predictable; it creates a sense of community; and it makes it easier for people to work together. Accordingly, this is synonymous with the epitome of knowledge citizenship including knowledge sharing behaviour and commitment to lifelong learning.

If trust is a significant part of a knowledge citizen's makeup, what do we need to know and understand about trust to personify it in our knowledge relationships?

\section{What is trust?}

Trust is a relationship of reliance. A trusted party is presumed to seek to fulfil policies, ethical codes, law and their previous promises, similar to the requirements of a 'citizen'.

In social sciences, the degree to which one party trusts another is a measure of belief in the honesty, benevolence and competence of the other party. Trust is a mental state that cannot be measured directly. Confidence in the results of trusting may be measured through behaviour.

In psychology, trust is integral to the idea of social influence, that is, it is easier to influence or persuade someone who is trusting. The notion of trust is increasingly adopted to predict the acceptance of behaviour by others, institutions (government agencies) and objects such as machines but the perception of honesty, competence and value similarity are essential.

However, trust does not necessarily involve a belief in the good character, views or morals of the other party. For example, persons engaged in criminal activity usually trust each other to some extent. In addition, trust does not necessarily include an action that you and the other party are mutually engaged in. Trust is a prediction of reliance on action, based on what one party knows about the other party.

It is tempting to believe that trust derives from affinity and esteem - that we trust those whose characters make them trustworthy. While this is the case for personal relationships, competence is crucial for trust in a business context, that is, it is not enough that Brutus is an honourable man, he must be an honourable man who knows his way around a balance sheet 
(Joni:on-line).

\section{Citizen's view of trust in today's society}

Public trust connotes the following:

- To have confidence in something/someone and hence be able to rely on someone

- To have expectations and hence hope

- To entrust and hence give custody

- Something given to one's care for the benefit or interest of another, hence charge/authority

- To account for entrusted power and authority, hence accountability (Khan, 2007).

Building trust includes democracy, freedom of information and access to information, free media, decentralization and opportunities for civic engagement in socio economic governance (Khan, 2007).

Global trends in trust show that trust levels in national governments, organizations such as the United Nations and global companies are at an all time low and while NGOs still enjoy higher trust levels than the aforementioned, they too have suffered setbacks (Khan, 2007).

In 2000, a poll found that 35\% of Americans said 'most people' could be trusted. In 2002, USA TODAY/CNN/Gallup Poll conducted a national poll of 1013 people and found that, in the aftermath of 9/11, Americans have developed greater trust in each other with 41\% admitting that they have trust in others. It is apparent that Americans appear to be relying more on themselves and the advice of family and friends, and less on employers, organizations and institutions.

By stark contrast, trust in Corporate America is eroding as incidents of fraud, investment ethical lapses and greed are exposed. More than seven in ten Americans say that they distrust the CEOs of large corporations. Nearly eight in ten believe that the top executives of large companies will take 'improper actions' to help themselves at the expense of their companies. In the past nine months, the percentage of Americans who say that they see 'big business' as an actual threat to the nation's future has nearly doubled, to $38 \%$.

What implications does this have for knowledge citizenship? Clearly trust matters. It is society's 'super glue'. Experts say an abundance of trust can lead to spurts of energy that benefit the common good, an example being the growth that followed the end of World War II, when the nation learned it could work together. Despite corporate distrust, 9/11 appears to have triggered something much more important and long lasting: a great national sense of connection, with citizens appearing to rely more on themselves and the advice of family and friends and less on employers, organizations and institutions.

\section{Trust as a prerequisite for knowledge sharing}

A primary attribute of a knowledge citizen is the ability to share knowledge, which essentially involves a person guiding someone else through their thinking or using their insights to help others see their own situation better. Furthermore, the person who shares and distributes knowledge ideally is, or should be, aware of the knowledge purpose, use, needs or gaps of the person receiving the knowledge. However, knowledge-sharing barriers are often related to factors such as a lack of communication skills and social networks, differences in national culture, a lack of time and, ultimately, trust.

Most people are unlikely to share their knowledge without a feeling of trust, that is, trust that 
people do not misuse their knowledge, or trust that knowledge is accurate and credible due to the information source. A detailed assessment of the quality of external tacit or explicit knowledge is often impossible due to the source and time constraints. It is mostly in informal networks that people trust each other, voluntarily share knowledge and insights with each other and collaborate actively and willingly.

\section{Types of trust}

Knowledge citizens can display a variety of trust types including the following:

- Personal trust, which is based on faith in a person's integrity, is trust at its most fundamental and widely understood. It is the trust of confidences shared without thought of betrayal, ideas revealed without fear of appropriation and tasks doled out to team-mates with the assurance that they will try hard not to let you down. Personal trust develops in the workplace through shared experiences and knowledge of colleagues' characters. High personal trust exists when we recognize the following traits: a person is honest and ethical, he or she will make good on his or her word, he or she is well intentioned, will handle confidential information with care and discretion and will be straightforward about what he or she does not know (Joni:on-line).

- Expertise trust is the reliance on an adviser's ability in a specific subject area. The parameters of expertise trust tend to be limited to a particular content area. High expertise trust exists when we recognize the following traits: a person is an expert in his or her field, his or her knowledge is up to date, he or she presents credible information to support his or her position, he or she is able to apply his or her expertise to our specific situation, and he or she can offer sage advice on risks, options and trade offs (Joni:on-line).

\section{Factors that influence trust}

A number of conditions may have an effect on trust relationship, including the following:

- Number of similarities. Most people tend to more easily trust those who appear similar to themselves. Similarities may include common values (strong work ethic), membership of a defined group (department, social club, community of practice or even a gender) and shared personality traits (extroversion, ambition). In deciding how much to trust someone, people often begin by tallying up their similarities and differences (Hurley:on-line).

- Alignment of interests. Before a person places his or her trust in someone else, he or she carefully weighs the question 'how likely is this person to serve my interests?' When people's interests are completely aligned, trust is a reasonable response. In reality, people have both common and unique interests (Hurley:on-line).

- Capability. This involves competence and capability that is routinely assessed when deciding to trust (Hurley:on-line).

\section{Rules of trust}

Trust is tenuous, at times difficult to build yet easily destroyed. For trust relationships to develop and thrive, a number of rules, albeit unwritten, apply, namely:

- Trust is not blind - it is unwise to trust people who are not committed to the same goals.

- Trust needs boundaries - meaning confidence in someone's competence.

- Trust demands life-long learning - the ability to change, to be flexible enough to change when time and circumstance demand it, keeping abreast of change, constantly 
exploring new options and new technologies, and being capable of self-renewal.

- Trust needs bonding - trust is not an impersonal commodity, it includes personal connections.

- Trust requires leadership - to raise people's vision and performance to a higher standard and to build personality beyond its normal limitations (Handy:on-line).

\section{Conclusion}

There are many similarities between the characteristics of a knowledge citizen and the characteristics of trust. A knowledge citizen is someone who gives of his or her time and talent for people, and citizenship is akin to the concept of membership, thus replacing the sense of belonging to a place with a sense of belonging to a community. Trust is the underlying bond that brings knowledge citizens together and gives them a sense of belonging, and it is something that society as a whole needs to thrive.

\section{References}

Handy, C. Trust and the virtual organisation. Harvard Business Review [Online Version]. Available WWW http://harvardbusinessonline.hbsp.harvard.edu/hbsp/hbr/articles/article.jsp? ml_action=get-article\&articleID=95304\&ml_page=1\&ml_subscriber=true.

Hurley, R.F. The decision to trust. Harvard Business Review [Online Version]. Available WWW http:// http://harvardbusinessonline.hbsp.harvard.edu/hbsp/hbr/articles/article.jsp? ml_action=get-article\&articleID=R0609B\&ml_page=1\&ml_subscriber=true.

Joni, SNA. The geography of trust. Harvard Business Review [Online Version]. Available WWW http://harvardbusinessonline.hbsp.harvard.edu/hbsp/hbr/articles/article.jsp? ml_action=get-article\&articleID=R0403F\&ml_page=1\&ml_subscriber=true.

Wikipedia. 2007. Trust (social sciences). [Online]. Available WWW: http://en.wikipedia.org/wiki/Trust_(sociology).

\section{Reading list}

Adkil Khan, M. 2007. Building trust in government: improving public management through civic engagement. [Online]. Available WWW

http://unpan1.un.org/intradoc/groups/public/documents/un/unpan025946.pdf.

Horowitz. B. 2003. Trust and corporate america. [Online]. Available WWW http://www.usatoday.com/educate/college/business/casestudies/20030227-corporatetrust.pdf.

Riege, A. 2005. Three-dozen knowledge-sharing barriers managers must consider. Journal of Knowledge Management. Emerald Group Publishing Limited. Vol 9(3):18 -35.

\section{About the author}

Melanie Sutton (BA, Postgraduate Diploma in Information Management) is a Senior Principal Consultant in the Enterprise Content Management Discipline and a member of Intellectual Property Forum at The IQ Business Group, South Africa.

\section{Disclaimer}

Articles published in SAJIM are the opinions of the authors and do not necessarily reflect the opinion of the Editor, Board, Publisher, Webmaster or the Rand Afrikaans University. The user hereby waives any claim 
he/she/they may have or acquire against the publisher, its suppliers, licensees and sub licensees and indemnifies all said persons from any claims, lawsuits, proceedings, costs, special, incidental, consequential or indirect damages, including damages for loss of profits, loss of business or downtime arising out of or relating to the user's use of the Website.

ISSN 1560-683X

Published by InterWord Communications for Department of Information and Knowledge Management, University of Johannesburg 